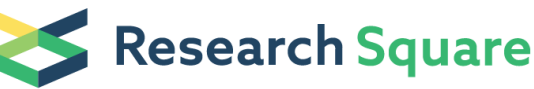 \\ Preprints are preliminary reports that have not undergone peer review. \\ They should not be considered conclusive, used to inform clinical practice, or referenced by the media as validated information.
}

\section{Prevalence and Types of Gender-Based Violence among Secondary School Students During Covid-19 Pandemic in Anambra State, South-East Nigeria}

\section{Ifeoma Bridget Udigwe}

Nnamdi Azikiwe University Faculty of Medicine: Nnamdi Azikiwe University Faculty of Medical Sciences Chioma Phyllis Nnamani ( $\mathbf{c}$ cp.nnamani@unizik.edu.ng )

Nnamdi Azikiwe University Faculty of Medicine: Nnamdi Azikiwe University Faculty of Medical Sciences https://orcid.org/0000-0002-2610-7397

\section{Chioma Chetachukwu Ajator}

Nnamdi Azikiwe University Faculty of Medicine: Nnamdi Azikiwe University Faculty of Medical Sciences

Chioma Pauline Mbachu

Nnamdi Azikiwe University Faculty of Medicine: Nnamdi Azikiwe University Faculty of Medical Sciences Ogochukwu Chioma Ofiaeli

Nnamdi Azikiwe University Faculty of Medicine: Nnamdi Azikiwe University Faculty of Medical Sciences Ahoma Victor Mbanuzuru

Nnamdi Azikiwe University Faculty of Medicine: Nnamdi Azikiwe University Faculty of Medical Sciences Uche M Umeh

Chukwuemeka Odumegwu Ojukwu University Faculty of Clinical Medical Sciences

\section{Research}

Keywords: Gender-based violence (GBV), COVID-19, STATA version 16.0.

Posted Date: November 2nd, 2021

DOI: https://doi.org/10.21203/rs.3.rs-968688/v1

License: (a) (1) This work is licensed under a Creative Commons Attribution 4.0 International License. Read Full License 


\section{Abstract}

Background: Gender-based violence (GBV) increases during every type of emergency whether economic crises, conflicts or disease outbreak like in the case of Coronavirus Disease of 2019 (COVID-19) pandemic. This study aimed to determine the prevalence and types of GBV among secondary school students during the COVID-19 pandemic in Anambra State, South East, Nigeria.

Methods: The study was a cross-sectional study, conducted among 403 secondary school student who were recruited consecutively after consent and assent were gotten. Self-administered semi-structured questionnaire was used to collect the data. Data was analysed using STATA version 16.0. The level of significance for test of association was set at $p$-value $<0.05$

Results: The prevalence of GBV was $63.28 \%$, emotional/verbal abuse were the most prevalent type while sexual abuse was the least type ( $85.5 \%$ vs $8.2 \%$ ). The highest perpetrator of the emotional/verbal abuse were their fellow students (64.8\%). The relationship between GBV and impact of abuse was statistically significant for academic performance, alcohol and tobacco intake (p-values: 0.040, 0.010, 0.029 respectively)

Conclusion: The prevalence of GBV is high among students during the COVID-19 pandemic, with the emotional/verbal type being the most prevalent type. GBV has an impact on their academic performance and social lives. We therefore recommend that stakeholders should have target programs to address the diverse effects of GBV on students especially with the pandemic.

\section{Background}

The adolescent is a time of transition in young people's life and it is associated with emotional disorders and high-risk behaviours. Gender inequalities and differences in economic and social life in adolescent influence their health and development. (1)

Gender-based violence (GBV) is the most pervasive yet least visible human rights violation in the world. (2) It undermines the health, dignity, security and autonomy of its victims, yet it remains shrouded in a culture of silence. (3) GBV is violence directed against a person because of that person's gender or violence that affects persons of a particular gender disproportionately. (4) This implies that violence is directed against boys or girls as a direct consequence of their biological sex or due to their gender identity. (5)

Pre-existing toxic social norms, economic and social stress caused by the pandemic, coupled with restriction of movement, have led to an exponential increase in GBV.(6) In areas where social norms lead to greater disparities between girls and boys in enrolment and retention in school, temporary disruption as a result of a crisis such as COVID-19 can lead to permanent removal from school. Families who are unable to pay school fees due to loss of income during the crisis, the loss of educational infrastructure 
are prominent concerns. This will have long-term negative impacts on girls, access to opportunities and resources to improve their lives, educational, economic and health outcomes.(7)

GBV can take various forms such as physical (results in injuries, distress and health problems), sexual, psychological (controlling, coercion, blackmail) and economic abuse. Other forms are battery, forced/early marriage. Female genital mutilation, online violence, rape, sexual harassments, intimidation at school/work, forced prostitution etc.(1),(4)

The problem of gender-based violence reaches every corner of the world. (3) The numbers of women and girls affected by this problem are staggering. According to World Health Organization (WHO), as at 2013, one in every three women has been beaten, coerced into sex or abused in some other way - most often by someone she knows(8) and one in five women is sexually abused as a child. (9) The identified risk factors of GBV among college students in developed countries include alcohol consumption, history of witnessing parental violence, drug abuse(10) while in developing countries, the identified risk factors are childhood rural residences, alcohol consumption, psychostimulant consumption, witnessing domestic violence as a child, cigarette smoking, religious affiliation, marital status, campus residences, ethnicity, indigene-ship. (11),(12),(13)

Young victims of GBV are known to suffer a decline in their academic performances, they often drop out of school and this undermines the adolescents' capacity to positively deal with their sexuality, reduce unintended pregnancy and sexually transmitted diseases. (11) Therefore, school-related GBV is a serious obstacle to learning causing not only physical harm but also severe psychological and adverse educational consequences, posing a serious threat to the achievement of the Millennium Development Goals (MDGs) especially those related to education and gender equality. (13)

The prevalence is largely unknown and even reported cases portrays an iceberg appearance (1416) because fears of reprisal and the willingness by families of the children involved to reach an agreement on settlement with the perpetrators deepen a culture of silence (17) which promotes underreporting (18) and enables the problem to continue festering.

A review of the literature reveals that this is a global phenomenon $(14,19-21)$ with certain developed countries like the United States of America, United Kingdom and Canada having rates ranging from 3.7\% to $16.3 \%$. A study in Zimbabwe revealed that more than $80 \%$ of pupils who drop out from secondary schools do so as a result of one form of abuse or the other. (17) Another study conducted in Ethiopia observed that $59.9 \%$ of the study participant reported ever experiencing GBV in their lifetime. In the study, $16.8 \%$ experienced physical abuse only, $43.0 \%$ experienced sexual abuse only while $40.2 \%$ experienced both physical and sexual abuse. (11) Similarly, another study also carried out in Ethiopia, revealed the lifetime prevalence of GBV to be $63.2 \%$ with sexual abuse reported to be $37.2 \%$ and physical abuse had a prevalence rate of $56.3 \%$. (22) Although there is a paucity of data on the Nigerian situation of GBV, (18) the occurrence of its various forms in various parts of the country is well documented. In a study conducted in Kano, Northern Nigeria among university students observed that the overall prevalence of GBV was $58.8 \%$, specifically, $22.8 \%, 22.2 \%$ and $50.8 \%$ of the participants experienced physical, sexual and 
emotional abuse respectively. (13) Another study done among secondary school students in Kwara State found that at least one form of GBV was experienced by $89.1 \%$ of public and $84.8 \%$ of private school students. The study also observed that psychological violence was the commonest type of GBV experienced (public $72.5 \%$ vs private $69.2 \%$ ) while sexual violence was the least (public $41.4 \%$ vs private $37.4 \%$ ). (23) Cases of physical abuse ranged from $20.3 \%$ to $87.5 \%$, while emotionally abused cases were between $68.0 \%$ and $92.2 \%$ in a study conducted in Niger State. (24) Studies among secondary school adolescents in Ibadan and Enugu recorded a 29\% (25)and 10.2\% (18)overall prevalence rate of sexual abuse respectively.

It is generally agreed that children/young adults are the future generation, leaders of tomorrow and flag bearers of any nation and to adequately conduct these duties, the rights of the child must be protected. (26) Thus, it is worthwhile to study GBV in light of its far-reaching effects on the health of its victims and the nation at large. Researchers argue that GBV has dire implications for the Nigerian educational system as it presents a major drawback to the child's educational development $(20,27)$ and thus, hinders societal growth and development.

This study aims to determine the magnitude of the prevalence of GBV among secondary school students during COVID-19 Pandemic in Anambra State which will help to address the current gaps in knowledge about the phenomenon. It will also establish its baseline types of distribution thus assisting policymakers in planning programs that address/mitigate the associated observed negative effects. It will also assist physicians to have a high index of suspicion when handling children with these problems.

\section{Methods}

STUDY SETTING: This was a descriptive cross-sectional study that involved secondary school students aged 10 to 19 years who attended a health program for students in Nnewi, Anambra State, Nigeria. The students (both junior and senior students) were representatives of schools from Nnewi North, Nnewi South, Ekwusigo and Ihiala Local Government Area (LGA) of Anambra state, South-East, Nigeria.

Study Population: This comprised of secondary school students aged 10 - 19 years.

Inclusion Criteria: Secondary school students aged $10-19$ years whose parents and principals permitted to participate in the study and who gave assent and consent to participate in the study.

Exclusion criteria: Students who did not receive permission from their principals, receive consent from their parents or guardians, and did not give assent to participate in the study.

Sample Size Determination and Sampling technique: A total population study was done. Every student who attended the health program was given equal opportunity to participate in the study. A total of 450 students was recruited consecutively from various schools in 4 different Local Government Areas (LGA) for the health program. The schools sampled were those who permitted their students to attend the 
health program. The study was carried out in December 2020 at the reopening of schools after the lockdown period in Nigeria.

Data collection tool: Data was collected using self-administered, semi-structured questionnaire with information on the socio-demographic data, pattern of abuse, perpetrators, and outcome.

Data Analysis: Data was analysed using STATA Version 16.0. Frequencies and percentages were used to display the descriptive variables. The relationship between GBV and some variables was analysed using Chi-square (Fishers' exact where applicable). The level of significance for test of association was set at pvalue $<0.05$

\section{Results}

Out of 450 recruited students, 403 completely filled the questionnaire giving a response rate of approximately $90 \%$.

\section{Socio-demographics of the study participants}

More than half (56.82\%) of the study participants were aged between $13-15$ years. The mean age was $14 \pm 1.649$ years. A higher proportion (60.79\%) of the study participants were females, $71.96 \%$ were senior secondary school students, $81.39 \%$ were living with their parents, $25.56 \%$ lived with other adults apart from their parents, a higher proportion has both father and mother as businessmen and women $(65.26 \%$, $59.80 \%$ respectively). (Table 1 )

\section{Table 1: Socio-demographics of the study participants}




\section{SOCIO-DEMOGRAPHICS}

FREQUENCY

PERCENTAGE

\section{Age group}

10-12 years

50

12.41

13-15 years

229

56.82

16-18 years

121

30.02

19-21 years

3

0.74

Mean \pm SD

$14.6 \pm 1.649$

\section{Gender}

Female

245

60.79

Male

158

39.21

Class level

Junior secondary

113

28.04

Senior secondary

290

71.96

Are you living with your father and mother?

No

75

18.61

Yes

328

81.39

Highest level of education of father

No Formal Education

19

4.71

Primary School

62

15.38

Secondary School

164

40.69

University

158

39.21

Highest level of education of mother

No Formal Education

19

4.71

Primary School

27

6.70

Secondary School

163

40.45

University

194

48.14

\section{Occupation of father}

Business

263

65.26

Civil servant

52

12.90 


\begin{tabular}{|l|ll|}
\hline Clergy & 8 & 1.98 \\
\hline Driver & 8 & 1.98 \\
\hline Engineer & 16 & 3.97 \\
\hline Nealth worker & 3 & 0.74 \\
\hline Skilled worker & 10 & 2.48 \\
\hline Occupation of mother & 43 & 10.67 \\
\hline Business & & \\
\hline Civil servant & 241 & 59.80 \\
\hline Health worker & 93 & 23.08 \\
\hline Not working & 9 & 2.23 \\
\hline Skilled worker & 15 & 3.72 \\
\hline Do you live with any other adult apart from your parents/guardian? & & 11.17 \\
\hline No & 45 & \\
\hline Yes & 300 & 74.44 \\
\hline Number of siblings & 103 & 25.56 \\
\hline 0 to 4 & & 0.74 \\
\hline 5 to 9 & 258 & 64.02 \\
\hline 10 to 14 & 140 & 34.74 \\
\hline 20 to 24 & 3 & 0.70 \\
\hline Mean \pm SD & 2 & \\
\hline Total & 403 & \\
\hline & & \\
\hline
\end{tabular}

Prevalence of Gender-based violence among the study participants

The prevalence of gender-based violence is $63.28 \%$. (Table 2)

Table 2: Prevalence of Gender-based violence among the study participants. 


\begin{tabular}{|lll|}
\hline Variable(N=403) & \multicolumn{2}{c|}{ Prevalence (\%) } \\
\cline { 2 - 3 } & No & Yes \\
\hline Have you ever felt abused in the past? & $148(36.72)$ & $255(63.28)$ \\
\hline
\end{tabular}

Prevalence of the specific types of GBV among the study participants.

Emotional and verbal abuse was the most prevalent type of GBV while sexual abuse was the least prevalent type ( $85.5 \%$ vs $8.2 \%)$. (Table 3 )

Table 3: Prevalence of the specific types of GBV among the study participants.

\begin{tabular}{|ll|}
\hline VARIABLE $(n=255)$ & PREVALENCE (\%) \\
\hline Physical abuses & $209(82.0)$ \\
\hline Emotional and verbal abuses & $218(85.5)$ \\
\hline Physical neglection & $100(39.2)$ \\
\hline Sexual abuses & $21(8.2)$ \\
\hline
\end{tabular}

The overall prevalence of the perpetrators of all the forms of GBV to the study participants.

Step-father (78.8\%) was the highest perpetrator followed by fellow students (64.8\%). Also step-father (78.8\%) was the highest perpetrator of physical abuse, fellow student (64.8\%) was the highest perpetrator of emotional/verbal abuse, mother (9.4\%) was the highest perpetrator of physical neglect while teacher $(2.4 \%)$ was the highest perpetrator of sexual abuse. (Table 4$)$

Table 4: The overall prevalence of the perpetrators of all the forms of GBV to the study participants. 


\begin{tabular}{|llllll|}
\hline $\begin{array}{l}\text { Perpetrators of } \\
\text { abuse }\end{array}$ & \multicolumn{2}{l}{ Forms of abuses (\%) } & \multicolumn{2}{l|}{ Total } \\
\cline { 2 - 4 } & $\begin{array}{l}\text { Physical } \\
\text { abuses }\end{array}$ & $\begin{array}{l}\text { Emotional and verbal } \\
\text { abuses }\end{array}$ & $\begin{array}{l}\text { Physical } \\
\text { neglect }\end{array}$ & $\begin{array}{l}\text { Sexual } \\
\text { abuses }\end{array}$ & \\
\hline Father & $39(15.3)$ & $21(8.2)$ & $18(7.1)$ & Nil & $78(30.6)$ \\
\hline Mother & $56(22.0)$ & $27(10.6)$ & $24(9.4)$ & $1(0.4)$ & 108 \\
\hline Siblings & $38(14.9)$ & $28(11.0)$ & $17(6.7)$ & Nil & $83(32.6)$ \\
\hline Teacher & $46(18.0)$ & $15(5.9)$ & $7(2.7)$ & $6(2.4)$ & $74(29.0)$ \\
\hline Fellow student & $52(20.4)$ & $95(37.3)$ & $13(5.1)$ & $5(2.0)$ & 165 \\
\hline Step father & $201(78.8)$ & Nil & Nil & Nil & 201 \\
\hline Step mother & $10(3.9)$ & $2(0.8)$ & $2(0.8)$ & Nil & $14(5.5)$ \\
\hline Guardian & $13(5.1)$ & $21(8.2)$ & $9(3.5)$ & $2(0.8)$ & $45(17.6)$ \\
\hline Relatives & $8(3.1)$ & $12(4.7)$ & $9(3.5)$ & $1(0.4)$ & $30(11.7)$ \\
\hline Non -relatives & $\mathrm{Nil}$ & $12(4.7)$ & $5(2.0)$ & $4(1.6)$ & $21(8.3)$ \\
\hline Others & $\mathrm{Nil}$ & $\mathrm{Nil}$ & $\mathrm{Nil}$ & $\mathrm{Nil}$ & $\mathrm{Nil}$ \\
\hline
\end{tabular}

The patterns physical violence among the study participants

More than half of the study participants (54.9\%) experienced beaten with an object as a pattern of physical violence, this was closely followed by hit/punched (54.1\%). (Table 5)

Table 5: The patterns physical violence among the study participants

\begin{tabular}{|ll|}
\hline PATTERN OF PHYSICAL VIOLENCE $(n=255)$ & PREVALENCE (\%) \\
\hline Hit/ Punched & $138(54.1)$ \\
\hline Kicked & $82(32.2)$ \\
\hline Beaten with an object & $140(54.9)$ \\
\hline Shaken hard & $51(20.0)$ \\
\hline Cut / stabbed on purpose & $26(10.2)$ \\
\hline
\end{tabular}


The patterns of emotional/verbal violence among the study participants

Majority (80.8\%) of the study participants experienced insulted/criticized as a pattern of emotional/verbal violence. (Table 6)

Table 6: The patterns of emotional/verbal violence among the study participants

\begin{tabular}{|ll|}
\hline PATTERN OF EMOTIONAL/VERBAL VIOLENCE ( $n=255)$ & PREVALENCE (\%) \\
\hline Insulted / criticized & $206(80.8)$ \\
\hline Told you were unloved & $40(15.7)$ \\
\hline Told 'I wish you were not born / were dead' & $38(14.9)$ \\
\hline Threatened to be hurt/ killed & $40(15.7)$ \\
\hline Threatened to be abandoned & $25(9.8)$ \\
\hline
\end{tabular}

The patterns of physical neglect among the study participants

A higher proportion (19.2\%) of the study participants felt not important as a pattern of physical neglect experienced, this was followed by feeling of lack of support/help when needed. (Table 7)

Table 7: The patterns of physical neglect among the study participants

\begin{tabular}{|l|l|}
\hline PATTERN OF PHYSICAL NEGLECT $(n=255)$ & PREVALENCE (\%) \\
\hline Had to wear dirty/torn clothes & $22(8.6)$ \\
\hline Been abandoned hungry / thirsty & $29(11.4)$ \\
\hline Not taken care of when sick & $18(7.1)$ \\
\hline Felt you were not important & $49(19.2)$ \\
\hline Felt there is no one looking after you & $28(11.0)$ \\
\hline Felt no one is supporting you/helping when needed & $47(18.4)$ \\
\hline Been stopped from going to school/denied of school supplies & $19(7.5)$ \\
\hline
\end{tabular}

\section{Prevalence of sexual abuses among the study participants}

A higher proportion (3.47\%) of the study participant experienced made to have intercourse as a pattern of sexual abuse, followed by made to pose naked (2.73\%). (Table 8$)$ 
Table 8: Prevalence of sexual abuses among the study participants

\begin{tabular}{|ll|}
\hline PATTERN OF SEXUAL ABUSE $(n=255)$ & PREVALENCE $(\%)$ \\
\hline Exposed your private parts & $10(2.48)$ \\
\hline Made you pose naked & $11(2.73)$ \\
\hline Touched your private parts & $8(1.99)$ \\
\hline Made you touched each other's private parts & $8(1.99)$ \\
\hline Made you have intercourse & $14(3.47)$ \\
\hline
\end{tabular}

Relationship between the socio-demographics and the abuse status of the study participants.

There is a statistical difference between the occupation of the mother and abuse. $(x 2=10.21, p-v a l u e=$ 0.037) (Table 9)

Table 9: Relationship between the socio-demographics and the abuse status of the study participants. 


\begin{tabular}{|c|c|c|c|c|}
\hline \multirow[t]{2}{*}{ SOCIO-DEMOGRAPHICS } & \multicolumn{2}{|c|}{ EVER BEEN ABUSED } & \multirow{2}{*}{$\chi_{\text {value }}^{2}$} & \multirow{2}{*}{$\begin{array}{l}\mathrm{p}- \\
\text { value }\end{array}$} \\
\hline & $\begin{array}{l}\text { Not } \\
\text { abused }\end{array}$ & Abused & & \\
\hline \multicolumn{5}{|l|}{ Age group } \\
\hline $10-12$ years & $14(9.52)$ & $\begin{array}{l}28 \\
(11.29)\end{array}$ & & \\
\hline $13-15$ years & $\begin{array}{l}89 \\
(60.54)\end{array}$ & $\begin{array}{l}140 \\
(56.45)\end{array}$ & 2.35 & 0.502 \\
\hline $16-18$ years & $\begin{array}{l}44 \\
(29.93)\end{array}$ & $\begin{array}{l}77 \\
(31.05)\end{array}$ & & \\
\hline 19-21 years & Nil & $3(1.21)$ & & \\
\hline \multicolumn{5}{|l|}{ Gender } \\
\hline Female & $\begin{array}{l}96 \\
(64.86)\end{array}$ & $\begin{array}{l}149 \\
(58.43)\end{array}$ & 1.62 & 0.202 \\
\hline Male & $\begin{array}{l}52 \\
(35.14)\end{array}$ & $\begin{array}{l}106 \\
(41.57)\end{array}$ & & \\
\hline \multicolumn{5}{|l|}{ Class level } \\
\hline Junior secondary & $\begin{array}{l}34 \\
(22.97)\end{array}$ & $\begin{array}{l}76 \\
(30.16)\end{array}$ & 2.41 & 0.120 \\
\hline Senior secondary & $\begin{array}{l}114 \\
(77.03)\end{array}$ & $\begin{array}{l}176 \\
(69.84)\end{array}$ & & \\
\hline \multicolumn{5}{|c|}{ Are you living with your father and mother? } \\
\hline No & $\begin{array}{l}25 \\
(16.89)\end{array}$ & $\begin{array}{l}50 \\
(19.61)\end{array}$ & 0.46 & 0.596 \\
\hline Yes & $\begin{array}{l}123 \\
(83.11)\end{array}$ & $\begin{array}{l}205 \\
(80.39)\end{array}$ & & \\
\hline \multicolumn{5}{|c|}{ Highest level of education of father } \\
\hline No Formal Education & $7(4.73)$ & $12(4.71)$ & & \\
\hline Primary School & $\begin{array}{l}21 \\
(14.19)\end{array}$ & $\begin{array}{l}41 \\
(16.08)\end{array}$ & 2.97 & 0.397 \\
\hline Secondary School & $\begin{array}{l}54 \\
(36.49)\end{array}$ & $\begin{array}{l}110 \\
(43.14)\end{array}$ & & \\
\hline University & $\begin{array}{l}66 \\
(44.59)\end{array}$ & $\begin{array}{l}92 \\
(36.08)\end{array}$ & & \\
\hline \multicolumn{5}{|c|}{ Highest level of education of mother } \\
\hline No Formal Education & $4(2.72)$ & $14(5.49)$ & & \\
\hline
\end{tabular}




\begin{tabular}{|c|c|c|c|c|}
\hline Primary School & $11(7.48)$ & $16(6.27)$ & 6.01 & 0.111 \\
\hline Secondary School & $\begin{array}{l}51 \\
(34.69)\end{array}$ & $\begin{array}{l}112 \\
(43.92)\end{array}$ & & \\
\hline University & $\begin{array}{l}81 \\
(55.10)\end{array}$ & $\begin{array}{l}113 \\
(44.31)\end{array}$ & & \\
\hline \multicolumn{5}{|c|}{ Occupation of father } \\
\hline Business & $\begin{array}{l}92 \\
(62.59)\end{array}$ & $\begin{array}{l}171 \\
(67.32)\end{array}$ & & \\
\hline Civil servant & $\begin{array}{l}23 \\
(15.65)\end{array}$ & $\begin{array}{l}29 \\
(11.42)\end{array}$ & & \\
\hline Clergy & $4(2.72)$ & $4(1.57)$ & & \\
\hline Driver & $2(1.36)$ & $6(2.36)$ & 9.79 & 0.201 \\
\hline Engineer & $10(6.80)$ & $6(2.36)$ & & \\
\hline Health worker & Nil & $3(1.18)$ & & \\
\hline Not working & $3(2.04)$ & $5(1.97)$ & & \\
\hline Skilled worker & $13(8.84)$ & $\begin{array}{l}30 \\
(11.81)\end{array}$ & & \\
\hline \multicolumn{5}{|c|}{ Occupation of mother } \\
\hline Business & $\begin{array}{l}74 \\
(50.00)\end{array}$ & $\begin{array}{l}167 \\
(65.49)\end{array}$ & & \\
\hline Civil servant & $\begin{array}{l}40 \\
(27.03)\end{array}$ & $\begin{array}{l}53 \\
(20.78)\end{array}$ & & \\
\hline Health worker & $5(3.38)$ & $4(1.57)$ & 10.21 & $0.037 *$ \\
\hline Not working & $7(4.73)$ & $8(3.14)$ & & \\
\hline Skilled worker & $\begin{array}{l}22 \\
(14.86)\end{array}$ & $23(9.02)$ & & \\
\hline \multicolumn{5}{|c|}{$\begin{array}{l}\text { Do you live with any other adult apart from your } \\
\text { parents/guardian? }\end{array}$} \\
\hline No & $\begin{array}{l}116 \\
(78.38)\end{array}$ & $\begin{array}{l}184 \\
(72.16)\end{array}$ & 1.91 & 0.167 \\
\hline Yes & $\begin{array}{l}32 \\
(21.62)\end{array}$ & $\begin{array}{l}71 \\
(27.84)\end{array}$ & & \\
\hline \multicolumn{5}{|l|}{ Number of siblings } \\
\hline 0 to 4 & $\begin{array}{l}99 \\
(66.89)\end{array}$ & $\begin{array}{l}159 \\
(62.35)\end{array}$ & & \\
\hline
\end{tabular}




\begin{tabular}{|c|c|c|c|}
\hline 5 to 9 & Nil & $3(1.18)$ & 3.38 \\
\hline 10 to 14 & Nil & $2(0.78)$ & \\
\hline 20 to 24 & $\begin{array}{l}49 \\
(33.11)\end{array}$ & $\begin{array}{l}91 \\
(35.69)\end{array}$ & \\
\hline
\end{tabular}

*; statistically significant, $p$-value $\leq 0.05$

Relationship between abuse status and the consequences of abuses among the study participants

The relationship between GBV and the impacts of abuse (last class position, academic performance, alcohol intake, tobacco intake) were statistically significant. (p-values: 0.046, 0.040, 0.010, 0.029 respectively). (Table 10)

Table 10: Relationship between abuse status and the consequences of abuses among the study participants. 


\begin{tabular}{|c|c|c|c|c|}
\hline \multirow[t]{2}{*}{ VARIABLE } & \multicolumn{2}{|c|}{ EVER BEEN ABUSED } & \multirow[t]{2}{*}{$\chi^{2}$ value } & \multirow[t]{2}{*}{ p-value } \\
\hline & Not abused & Abused & & \\
\hline \multicolumn{5}{|c|}{ What was last Class position? } \\
\hline $1^{\text {st }}-10^{\text {th }}$ & $105(84.00)$ & $170(75.89)$ & & \\
\hline $11^{\text {th }}-20^{\text {th }}$ & $15(12.00)$ & $43(19.20)$ & & \\
\hline $21^{\text {st }}-30^{\text {th }}$ & $3(2.40)$ & $11(4.91)$ & 8.01 & $0.046^{*}$ \\
\hline $31^{\text {st }}-40^{\text {th }}$ & Nil & Nil & & \\
\hline$\geq 41 s t$ & $2(1.60)$ & Nil & & \\
\hline \multicolumn{5}{|c|}{ How has your school performance been? } \\
\hline Average & $37(25.00)$ & $94(37.15)$ & & \\
\hline Poor & $6(4.05)$ & $7(2.77)$ & 6.42 & $0.040 *$ \\
\hline Very good & $105(70.95)$ & $152(60.08)$ & & \\
\hline \multicolumn{5}{|c|}{ Do you take alcohol? } \\
\hline No & $142(95.95)$ & $224(88.19)$ & 6.90 & $0.010^{*}$ \\
\hline Yes & $6(4.05)$ & $30(11.81)$ & & \\
\hline \multicolumn{5}{|c|}{ Do you take tobacco? } \\
\hline No & $148(100.0)$ & $246(96.85)$ & 4.76 & $0.029 *$ \\
\hline Yes & Nil & $8(3.15)$ & & \\
\hline
\end{tabular}

*; statistically significant, $p$-value $\leq 0.05$

\section{Discussion}

This study focused on the prevalence, types and impact of gender-based violence among secondary school students. The overall prevalence of GBV observed in this study was $63.28 \%$. This finding is comparable with similar studies conducted within Africa, for instance a study carried out in Ethiopia found lifetime overall prevalence of GBV to be $63.8 \%(22)$, also another cross-sectional study conducted among high school students residing in rural areas of Hadiya zone in Ethiopia reported $62.2 \%$.

(28) Similarly another study carried out among female college students reported a prevalence rate of $59.9 \%$.(11) Within Nigeria, a study conducted in Northern Nigeria observed the prevalence of GBV to be 58.8\%.(13) Emotional/verbal violence was the most prevalent (85.5\%) type of GBV, while sexual violence $(8.2 \%)$ was the least prevalent type. Emotional/verbal violence is not overtly obvious and may be hidden from other people. Also, the true prevalence of the sexual form of violence may have been higher as some 
students may likely have denied the experience due to the fear of stigmatization.(23) lliyasu et al, (13) Fawole et al(23) and Letta et al(28) in their various studies reported similar findings.

From this study, step-father (78.8\%) was the highest perpetrator of physical violence, fellow student (64.8\%) was the highest perpetrator of emotional/verbal violence, mother (9.4\%) was the highest perpetrator of physical neglect while teacher $(2.4 \%)$ was the highest perpetrator of sexual violence in the present study. These findings may be attributed to the demographic of the study participants. Mothers being the highest perpetrators of physical neglect may be attributed to women in recent times has become breadwinners of the family, having little or no time for their children. Letta et al in their study found that children living with their step parents were more likely to be abused than those living with their parents.(28) This is the fact that step father or mother may not give proper care to the children and daily conflicts may be common. Also, the student may not obey for step parents who lead to conflict and physical injury.(28) Study conducted in Northern Nigeria, found that more than three fourths of victims of emotional/verbal violence were abused by male students.(13) Another study conducted in Southwest Nigeria also observed classmates to be perpetrators of emotional violence.(29) Various studies have also implicated teachers as culprits of sexual violence among students.(30),(31),(32)

More than half of the study participants (54.9\%) in this study, experienced beaten with an object as a pattern of physical violence, this was closely followed by hit/punched (54.1\%). This observation is in keeping with a study carried out in Ethiopia, where most of the participant reported beating with stick as the commonest mechanism of performing the physical violence.(28) However, this finding is at variant with various studies. (11), (13),(23),(33) This variations in findings may be attributed to the reported perpetrator of the patterns of the physical violence. For example lliyasu et al in their study reported being pushed or shoved as the most prevalent pattern of physical violence and male students were the perpetrators.(13) Another study conducted among secondary school students in Nigeria, found slap as the commonest pattern of physical violence with friends being the commonest perpetrator.

(23) Concerning the commonest pattern of emotional/verbal violence experienced in this study $80.8 \%$ of the study participants experienced being insulted/criticized. This finding is in agreement with studies conducted in Sudan and Nigeria where insults were reported as the commonest pattern of emotional/verbal violence experienced.(13),(33) A higher proportion (19.2\%) of the study participants felt not important as a pattern of physical neglect experienced, this was followed by feeling of lack of support/help when needed. On the contrary, a study carried out in Iran reported students' discomfort and having no welfare at home, lack of attention to students' demands, and parent's excessive expectations as the pattern of physical neglect experienced.(34) The difference could be due to the cultural differences in the participants of the two studies. Though, sexual form was the least experienced form of violence experienced by the study participants in this study, a higher proportion (3.47\%) of them were made to have intercourse, followed by made to pose naked $(2.73 \%)$. Other studies also reported similar findings in their various studies.(18),(28),(35)

From this study, there was a statistical difference between the occupation of the mother and abuse. $\left(x^{2}=\right.$ 10.21 , p-value $=0.037$ ). Majority of the mothers of the study participants were business women, and this 
type of occupation may give the mothers little or no time for their children, thereby predisposing them to the risk of abuse.

The relationship between academic performance, alcohol intake and tobacco use and GBV were statistically significant. This shows that GBV has an impact on the academic and social life of the abused and this may affect who they turn out to become as adults. This observation was reported in similar studies(22),(33),(36) where poor school performance, use of tobacco and alcohol were associated with GBV.

Study limitation: the study being a cross-sectional study, shows inability to make a causal inference as to the associations between GBV and consequences.

\section{Conclusion}

The prevalence of GBV is high among students during the COVID-19 pandemic, with the emotional/verbal type being the most prevalent type. GBV has an impact on their academic performance and social lives. We therefore recommend that stakeholders should have target programs to address the diverse effects of GBV on students especially with the pandemic.

\section{Abbreviations}

1. GBV: Gender-based Violence

2. COVID-19: Coronavirus Disease of 2019

3. WHO: World Health Organisation

4. MDG: Millenium Development Goals

\section{Declarations}

Ethical approval and consent to participate: The Nnamdi Azikiwe University Teaching Hospital Ethics Committee (NAUTHEC) was written for ethical approval of this study protocol. The reference number for the ethical approval is NAUTH/CS/66/VOL.14//VER.3/294/2021/078. Informed consent was obtained from the principals and parents of each participant/respondent one to two weeks prior to the study. Also, assent was obtained from each participant after thorough explanation of the objectives of the study. Each respondent was free to opt-out of the study at any time.

\section{CONSENT FORM}

We are researchers interested in the health of adolescents and young adults. We work in Nnamdi Azikiwe University Teaching Hospital, Nnewi. We want to conduct a study on gender based violence among secondary school students during COVID-19 pandemic in Anambra State 
Purpose of the study: This is to assess the prevalence and types of gender based violence among secondary school students during COVID-19 pandemic in Anambra State.

Procedure: The adolescent (10-19 years) will be asked some questions in the form of a questionnaire. The entire process will last about 15 minutes.

Confidentiality: The identity of the respondent in this study will be treated as confidential. The results of the study may be published for scientific purposes, but will not give the name or include any identifiable references of each respondent.

Possible Benefits: This study will help us including your child/ward to understand the issues of gender based violence during COVID-19 pandemic in Anambra State. It will also help the policy makers to plan adequate intervention where necessary.

Possible Risks: There are no known risks in participating in this study.

Voluntary Participation: Your child/ward is free to participate in this study or not, he/she has the right to withdraw at anytime. Hence, the permission to allow your child/ward to participate in this study is being sought.

Payment: We did not receive any grant for this study and no payment will be given to participants.

Authorization: I freely permit my ward/child to participate in the above study.

Name:

Signature and Date:

Principal Investigator's Signature and Date:

Phone Number: 08037231932

Signature of Person obtaining Consent (and Date):

Completing interests: There are no competing interests

Funding: The study was self-sponsored

Contributions: IBU conceptualized, designed the study, analysed the data, CPN curated the data, literature search, analysed the data. All the authors (IBU, CPN, CCA, CPM, OCO, AVM, UMU) collected the data, interpreted the data, drafted and revised the manuscript)

Acknowledgements

We appreciate the parents, principals and the teachers of the secondary schools for permitting their students to participate in this study. We are also grateful to the students for giving us their support during 
data collection.

\section{References}

1. Lelissa G, Yusuf L. A cross sectional study on prevalence of gender based violence in three high schools, Addis Ababa, Ethiopia. Ethiop J Reprod Heal. 2008;2(1):52-60.

2. UNICEF. Gender-based violence in emergencies [Internet]. [cited 2021 Feb 8]. Available from: https://www.unicef.org/protection/gender-based-violence-in-emergencies

3. United Nations Population Fund (UNFPA). Gender-based violence [Internet]. [cited 2021 Feb 8]. Available from: https://www.unfpa.org/gender-based-violence

4. European Commission. What is gender-based violence? [Internet]. [cited 2021 Feb 8]. Available from: https://ec.europa.eu/info/policies/justice-and-fundamental-rights/gender-equality/gender-basedviolence/what-gender-based-violence_en

5. World Health Organization (WHO). Violence against children [Internet]. [cited 2021 Feb 8]. Available from: https://www.who.int/news-room/fact-sheets/detail/violence-against-children

6. UNDP. Gender-based violence and COVID-19 [Internet]. UNDP Brief. 2020 [cited 2021 Sep 9]. p. 16. Available from: https://www.undp.org/publications/gender-based-violence-and-covid-19

7. United Nations Population Fund (UNFPA). Gender Based Violence in Africa during COVID 19 pandemic [Internet]. Policy Paper (UN Women-Africa). 2020 [cited 2021 Sep 9]. p. 20. Available from: https://africa.unwomen.org/en/digital-library/publications/2020/12/gbv-in-africa-during-covid-19pandemic

8. Sexual and Reproductive Health team. Global and regional estimates of violence against women: Prevalence and health effects of intimate partner violence and non-partner sexual violence [Internet]. World Health Organization (WHO). 2013 [cited 2021 Feb 8]. p. 51. Available from: https://www.who.int/publications/i/item/9789241564625

9. World Health Organization (WHO). Global status report on violence prevention [Internet]. WHO. World Health Organization; 2014 [cited 2021 Feb 8]. Available from: http://www.who.int/violence_injury_prevention/violence/status_report/2014/en/

10. Gross AM, Winslett A, Roberts M, Gohm CL. An examination of sexual violence against college women. Violence Against Women. 2006;12(3):288-300.

11. Arnold D, Gelaye B, Goshu M, Berhane Y, Williams MA. Prevalence and risk factors of gender-based violence among female college students in Awassa, Ethiopia. Violence Vict. 2008;23(6):787-800.

12. Philpart M, Goshu M, Gelaye B, Williams MA, Berhane Y. Prevalence and risk factors of gender-based violence committed by male college students in Awassa, Ethiopia. Violence Vict. 2009;24(1):122-36.

13. Iliyasu Z, Abubakar IS, Aliyu MH, Galadanci HS, Salihu HM. Gender-based Violence in Tertiary Institutions. Afr J Reprod Health. 2011;15(3):111.

14. Ajayi BT, B.O O. Parental Communication as a Tool Kit for Preventing Sexual Abuse among Adolescent Secondary School Students. J Educ Pract. 2016;7(13):116-23. 
15. Manyike P, Chinawa J, Aniwada E, Udechukwu N, Odutola O, Chinawa A. Child sexual abuse among adolescents in southeast Nigeria: A concealed public health behavioral issue. Paj J Med Sci. 2015;31(4):827-32.

16. Gabriel-Job N, Alikor E, Akani N. Prevalence of child sexual abuse among secondary school adolescents in Obio/Akpor Local Government Area of Rivers State, Nigeria. Niger J Paediatr. 2019;46(4):156-62.

17. Tshabalala T. Prevalence of cases of child abuse and their impact on performance of secondary school pupils in Zimbabwe: A case study of Nkayi District. J Educ Res. 2018;3(5):51-64.

18. Chinawa JM, Aronu AE, Chukwu BF. Prevalence and pattern of child abuse and associated factors in four secondary institutions in Enugu, Southeast Nigeria. Eur J Pediatr. 2014;173(4):451-6.

19. Lalor K. Child Sexual Abuse in Sub-Saharan Africa: A Literature Review. Child Abus Negl. 2004;28:439-60.

20. Aluede O, Ojugo A., Okoza J. Emotional abuse of secondary school students by teachers in Edo State, Nigeria. Res Educ. 2012;88(88):29-39.

21. Al-zboon E, Ahmad J, Al-dababneh K. Prevalence and types of childhood abuse among special education students attending Jordanian Universities. Int J Adolesc Youth. 2016;21(4):476-85.

22. Tantu T, Wolka S, Gunta M, Mohammed H, Duko B. Prevalence and determinants of gender-based violence among high school female students in Wolaita Sodo, Ethiopia: an institutionally based cross-sectional study. BMC Public Health. 2020;20:540.

23. Fawole OI, Balogun OD, Olaleye O. Experience of gender-based violence to students in public and private secondary schools in Ilorin, Nigeria. Ghana Med J. 2018;52(2):66-73.

24. Gyong J, Hellandendu J, Kolo J. Nature and Types of Maltreatment Suffered by Students of Secondary Schools in Niger State. Int J Humanit Soc Sci. 2015;5(9):257-61.

25. Balogun F, Adenowuro O. Prevalence and pattern of child sexual abuse: A cross-sectional study among male secondary school adolescents in Ibadan, Nigeria . J Child Adolesc Heal. 2020;4(1):1-8.

26. Jasmine KP, Hameed A. Child Abuse Awareness among Higher Secondary School Students. J Res Method Educ. 2016;6(4):75-9.

27. Okpechi PA. Child abuse and academic performance of Secondary school students in central senatorial district of Cross River State. Glob J Educ Res. 2013;12:47-54.

28. Letta T, Feleke A, Derseh L. Assessment of Violence and Associated Factors among Rural High School Female Students, in Hadiya Zone, Southern Nation and Nationalities Peoples' Region, Ethiopia, 2013. Open Access Libr J. 2014;1:659.

29. Ajuwon A, Fawole F, Osungbade K. Experience and Perpetration of Violent Behaviours among Secondary School Students in Ibadan, Nigeria. Sierra Leone J Biomed Res. 2011;3(1):27-35.

30. Shumba A. "Who Guards the Guards in Schools?" A Study of Reported Cases of Child Abuse by Teachers in Zimbabwean Secondary Schools. Sex Educ. 2001;1(1):77-86.

31. Burton P. Suffering at school: Results of the Malawi gender-based violence in schools survey. 2005. 
32. Alexander Y. Prevalence of Gender Based Violence in Northern Sierra Leone. Tech Rep Ser. 2017;2345.

33. Badri AY. SCHOOL-GENDER-BASED VIOLENCE IN AFRICA: PREVALENCE AND CONSEQUENCES. Glob J Arts Humanit Soc Sci. 2014;2(2):1-20.

34. Pirdehghan A, Esna-Ashari F, Gharebaghi A, Haghighi M, Ahmadpanah M, Rabiei MAS. Child abuse and neglect among iranian high school students. Iran J Pediatr. 2020;30(2):1-6.

35. Al-Eissa MA, Saleheen HN, Al-Wallan NS, AlKashan MY, AlSubaie NJ AM. Prevalence of sexual abuse among secondary school students in Saudi Arabia. Violence Vict. 2018;33(5):855-70.

36. Mullu G, Gizachew A, Amare D, Alebel A, Wagnew F, Tiruneh C, et al. Prevalence of Gender Based Violence and Associated Factors among Female Students of Menkorer High School in Debre Markos Town, Northwest Ethiopia. Sci J Public Heal. 2015;3(1):67-74.

\section{Supplementary Files}

This is a list of supplementary files associated with this preprint. Click to download.

- PrevalenceandpatternofGenderBasedViolence1.xlsx 